\title{
FABRICATION OF 2-5 $\mu$ M HYGROSCOPIC SEEDING MATERIAL FOR RAIN ENHANCEMENT PURPOSES
}

\author{
Pembuatan Bahan Semai Higroskopis Berukuran 2-5 $\mu$ M untuk Tujuan \\ Peningkatan Curah Hujan
}

\author{
Dini Harsanti ${ }^{1)^{*}}$, Krisna Adhitya ${ }^{1)}$, Safrizal'1) \\ 1) Balai Besar Teknologi Modifikasi Cuaca - Badan Pengkajian dan Penerapan Teknologi, Gedung Ir. \\ Mohammad Soebagio, GEOSTECH (820), Kawasan PUSPIPTEK, Serpong, Tangerang Selatan \\ *E-mail: dini.harsanti@bppt.go.id
}

\begin{abstract}
Hygroscopic cloud seeding, which uses giant cloud condensation nuclei (GCCN) particles with diameters between 2-5 $\mu \mathrm{m}$, has been known to be 100 times more effective compared to those that use hygroscopic flares. Micronisation through jet milling has been recognized as the most common and ubiquitous method used to obtain particles with such a narrow size $(2-5 \mu \mathrm{m})$ distribution. This research has successfully developed and identified 2-5 $\mu \mathrm{m} \mathrm{NaCl}$ powders mixed with $10 \%$ cab-o-sil anticaking agent and 2 (two) times jet milling frequency as a potential GCCN (hygroscopic) seeding material. We use a combination of jet mill micronisation, rough milling with a Cross-Beather Mill, and analytical sieving to produce powders with those mentioned above $(2-5 \mu \mathrm{m})$ size distribution. We varied the anticaking agent percentage in the mixture and the jet milling process frequency to identify which parameters would result in the 2-5 $\mu \mathrm{m}$ size distribution. We then confirmed the micronisation results particle size distribution with a particle size analyzer (PSA) and its morphology with a scanning electron microscope (SEM) machine. The materials with the 10\% cab-o-sil agent mixture were confirmed to have the aforementioned size distribution from the characterization results.
\end{abstract}

Keywords: Hygroscopic Cloud Seeding, GCCN, Jet Milling

\section{Intisari}

Penyemaian awan higroskopis menggunakan partikel giant cloud condensation nuclei (GCCN) dengan diameter 2-5 $\mathrm{m}$ telah diketahui 100 kali lebih efektif dibandingkan dengan yang menggunakan flare higroskopis. Mikronisasi melalui jet milling telah dikenal sebagai metode yang paling umum dan banyak digunakan untuk mendapatkan partikel dengan distribusi ukuran sempit (2-5 $\mu \mathrm{m})$. Penelitian ini berhasil mengembangkan dan mengidentifikasi serbuk $\mathrm{NaCl} 2-5 \mu \mathrm{m}$ yang dicampur dengan 10\% anti gumpal berupa Cab-O-Sil dan frekuensi jet milling 2 (dua) kali sebagai bahan penyemaian GCCN (higroskopis) potensial. Pada penelitian ini telah digunakan kombinasi mikronisasi jet mill, penggilingan kasar dengan Cross-Beather Mill, dan ayakan analitik untuk menghasilkan serbuk dengan distribusi ukuran yang disebutkan di atas (2-5 $\mu \mathrm{m})$. Telah divariasikan pula persentase bahan anti gumpal dalam campuran dan frekuensi proses jet milling untuk mengidentifikasi parameter yang akan menghasilkan distribusi ukuran 2-5 $\mu$ m. Distribusi ukuran partikel hasil mikronisasi tersebut kemudian dikonfirmasi dengan alat analisa ukuran partikel (PSA) dan morfologinya dengan mesin scanning electron microscope (SEM). Dari hasil karakterisasi, material dengan campuran anti gumpal Cab-O-Sil sebanyak 10\% dipastikan memiliki sebaran ukuran tersebut.

\section{Kata Kunci: Penyemaian Awan Higroskopis, GCCN, Jet Milling}

\section{INTRODUCTION}

Weather Modification Technology (TMC) in the form of cloud seeding is divided into two types based on the type of the clouds being seeded; the first one is cold-cloud seeding, and the second is warm-cloud seeding (Braham RR, 1986; Bruintjes R.T., 1999). In cold-cloud seeding, seeding is carried out in "cold" clouds or clouds experiencing supercooling conditions, where water or water droplets in the cloud are at temperatures below 0 ${ }^{\circ} \mathrm{C}$. In these conditions, in addition to water droplets, there is also water in the form of ice crystals in the cloud. If the ice crystals are near the very cold-water droplets, the water droplets will undergo a phase change, and the crystal ice will grow and by itself will cause the growth of clouds of that type. If seeding materials with the same characteristics as the ice crystals are added into the very cold cloud system, the growth of ice 
crystals and very cold-type clouds will occur more rapidly. The characteristic of these seeding materials is that the materials must be in the ice phase or act as an ice condensation core at a temperature of $-5^{\circ} \mathrm{C}$ or less (Cooper W.A. et al., 1997). This method is commonly used in countries located in the mid-latitude region, for example, countries with a subtropical climate. Some examples of seeding materials used in this method are dry ice (CO2 in solid form) and Agl compounds.

In the warm-cloud seeding method, seeding is done on "warm" clouds or clouds that are in a supersaturated state (Czys RR \& Bruintjes RT, 1994; Drofa AS et al., 2010). In this type of cloud, the number of water droplets formed from water vapor condensation is much more than the actual amount of water vapor in the cloud. In other words, the relative humidity $(\mathrm{RH})$ of the cloud is more than $100 \%$. These clouds generally have a peak height of at least $3350 \mathrm{~m}$ but not higher than the altitude where water vapor is in the ice phase, which is around 4900-5500 m (Silverman, 2000). Therefore, this seeding method is widely used in the tropics because the characteristics of the clouds are "warm" types. In this cloud, the number of water droplets can increase through a condensation process under supersaturation conditions and a process of collision and coalescence with other water droplets. When water droplets or an artificial condensation core are released into this type of cloud, cloud growth can occur faster than the natural one. In this method, the material used for seeding is divided into two categories, which are the seeding material in the form of water droplets and the hygroscopic seeding materials.

McFiggans G et al. (2006) and Sullivan RC et al. (2009) mentioned that hygroscopic materials could be used as seeding materials in cloud seeding activities because their ability to absorb water in quantity can activate the material and become the condensation core of the cloud. This ability is mainly determined by the particle size and hygroscopic chemical content of the dissolved material (McFiggans $\mathrm{G}$ et al., 2006; Sullivan R.C. et al., 2009). The hygroscopic seeding materials can then increase condensation, collisions, and incorporation in the cloud structure. Examples of hygroscopic seeding materials that are widely used in seeding activities around the world include $\mathrm{CaCl} 2, \mathrm{NaCl}$, Urea, and $\mathrm{NH} 4 \mathrm{NO} 3$.

Sodium chloride $(\mathrm{NaCl})$ is a hygroscopic inorganic salt widely present in the form of aerosols in free air and can be activated to form cloud condensation nuclei at less than $100 \mathrm{~nm}$ diameter (McFiggans G et al., 2006). Harmon CW et al. (2010) wrote that large $\mathrm{NaCl}$ crystals at relative humidity above $70 \%$ could absorb up to 3.5-4 monolayers of water onto the surface of the $\mathrm{NaCl}$ crystal. In certain $\mathrm{RH}$ conditions, namely $\mathrm{RH}$ deliquescence (DRH) conditions, the $\mathrm{NaCl}$ crystal phase will undergo a transition to the solution phase accompanied by adsorption of a certain amount of water onto the crystal surface. This transition is called the deliquescence transition.

Based on the modeling result by Segal et al. (2004), the optimal size of cloud seeding material particles used for rain enhancement purposes is around 2-5 $\mu \mathrm{m}$. Moreover, the results of an experiment by Rosenfeld et al. (2010) showed that seeding material in this range of size has 100 times greater effectivity than hygroscopic flare in producing GCCN (Giant Cloud Condensation Nuclei) that then become rain embryos. The seeding material used in Rosenfeld et al.'s experiment (2010) is $\mathrm{NaCl}$ salt powder that is mixed with aerosil (SiO2) as its anticaking agent.

This research has successfully developed and identified 2-5 $\mu \mathrm{m} \mathrm{NaCl}$ powders mixed with a cab-o-sil anticaking agent as a potential GCCN (hygroscopic) seeding material. We use a combination of jet mill micronisation, rough milling with a Cross-Beather Mill and analytical sieving in order to produce powders with the aforementioned $(2-5 \mu \mathrm{m})$ size distribution (Clark A.R., et al.,1996; Gommeren H.J.C., et al.,1996; Gary Liu, PE, 2017). We varied the anticaking agent percentage in the salt-agent mixture and the frequency of jet milling to identify which parameters would result in the 2-5 $\mu \mathrm{m}$ size distribution. We then identified and confirmed the micronisation results in particle size distribution with a particle size analyzer (PSA) and its morphology with a scanning electron microscope (SEM) machine. From the (milling) results, materials with $10 \%$ cab-o-sil agent mixture and 2 (two) times jet milling frequency were found to contain $\mathrm{NaCl}$ particles with 2-5 $\mu \mathrm{m}$ size distribution. Hence, offering the possibility to produce such material in large quantities.

\section{METHODS}

\subsection{Materials and Equipments}

The main hygroscopic material used in this research is a common crude seawater salt sourced from Cirebon, West Java, Indonesia. Besides, fumed silica ( $\mathrm{SiO} 2)$ was used as the anticaking agent in the cloud seeding material mixture. The fumed silica used in this research was from Cabot Corporation, namely fumed silica Cab-O-Sil M5. Later, this anticaking is mentioned as Cab-O-Sil in this paper.

A Cross-Beather Mill of the Pulverisette 16 model from Fritsch, $\mathrm{GmbH}$ was used as the rough milling machine. To sieve the roughly milled sample, a HAVER EML 200 PURE model of Haver \& Boecker $\mathrm{GmbH}$ sieve shaker was used. The micronization process was conducted by using the Sturtevant model Micronizer 4 jet mill. The heating treatment in this research was conducted by using Model TR 450 from the Nabertherm 
GmbH oven. Samples' analysis includes morphologies and material composition was characterized by Scanning Electron Microscope equipped with Energy Dispersive X-Ray Spectrometer SEM-EDX Hitachi SU3500 in Research Center for Physics LIPI. SU3500 allows effective image analysis with multiple signals in one image, the secondary electron (SE) providing material surface rich information and the backscattered electron (BSE) signal for material compositional information. Meanwhile, particle size and particle size distribution analysis were characterized by Particle Size Analyzer Nano DS Cilas (Nano Plus Particulate System) in Research Center for Material BPPT.

\subsection{Experiments}

Initially, as much as $1 \mathrm{~kg}$ crude seawater salt was crushed manually by using mortar. After that, the manually crushed salt was heated at 125 ${ }^{\circ} \mathrm{C}$ for 1 hour. The heated salt was then milled using Cross-Beather Mill two times. Both millings were conducted at a mill speed of $2000 \mathrm{rpm}$. The first milling used an output screen of $1 \mathrm{~mm}$, while the second used an output screen of $0.5 \mathrm{~mm}$. The twice milled sample was sieved using a sieve shaker for 10 minutes. Sieving was conducted to obtain a smaller distribution of salt particle sizes from the milled sample. The sieves were those of 180 micrometer, 150 micrometer, and 75 micrometers. These sieve mesh sizes $(180,150$ and $75 \mu \mathrm{m}$ ) were chosen because they were the three smallest mesh sizes available at the time of writing this paper. Below the stack of the sieves was a pan that collected the fraction of samples with the lowest sizes (less than 75 micrometer). The sample obtained in the pan was then divided into four parts to be mixed with Cab-O-Sil $0 \%, 3 \%$, $5 \%$, and $10 \%$. The four mixtures were then reheated at $125{ }^{\circ} \mathrm{C}$ for 1 hour. Each of the heated samples was then milled two times by using a jet mill. The second milled samples and the third milled samples were collected and analysed using a scanning electron microscope (SEM) and particle size analyzer (PSA).

\section{RESULTS AND DISCUSSIONS}

The raw material of $\mathrm{NaCl}$ generally has high water content due to its hygroscopicity. The examination of crude seawater salts from some regions in Indonesia shows that water content values range from $5.47 \%$ to $12.92 \%$. Therefore, heating treatment is important to reduce the water content. Heating treatment to remove water content in a material is basically by heating the material above the boiling point of water for a certain time. In this research, the chosen temperature was $125{ }^{\circ} \mathrm{C}$. This temperature of choice is also considered the Cab-O-Sil that cannot be heated above $150^{\circ} \mathrm{C}$.
As described in the method section, the sample that Cross-Beather Mill milled was sieved by a sieve shaker. The only sample in the pan that passed through the sieve of the smallest size (75 micrometers) was processed further for the next steps. From $1 \mathrm{~kg}$ raw material used as an initial weight in this part, about a $0.3 \mathrm{~kg}$ sample was obtained in the pan in the sieving process. The sample was divided into four to be processed in the next steps as different samples: sample with 0\% Cab-O-Sil, 3\% Cab-O-Sil, 5\% Cab-O-Sil, and 10\% Cab-O-Sil.

Based on SEM images in Figure 1, the resulting particle diameter range and its mean diameter is displayed in Table 1. Based on those data, the particle sizes of $2 x$ jet-milled samples had been generally in the range of $2-5 \mu \mathrm{m}$.

Table 1. Particle diameter range and mean diameter based on SEM image in Figure 1.

\begin{tabular}{|c|c|c|c|}
\hline No. & Sample & $\begin{array}{c}\text { Particle } \\
\text { Diameter Range } \\
(\mu \mathrm{m})\end{array}$ & $\begin{array}{c}\text { Particle Mean } \\
\text { Diameter }\end{array}$ \\
\hline 1. & $\begin{array}{c}\mathrm{NaCl}+3 \% \\
\mathrm{Cab}-\mathrm{O}-\mathrm{Sil}\end{array}$ & $4.14-5.41$ & $(4.80 \pm 0.01)$ \\
\hline 2. & $\begin{array}{c}\mathrm{NaCl}+5 \% \\
\mathrm{Cab}-\mathrm{O}-\mathrm{Sil}\end{array}$ & $3.81-5.91$ & $(4.76 \pm 0.01)$ \\
\hline 3. & $\begin{array}{c}\mathrm{NaCl}+10 \% \\
\mathrm{Cab}-\mathrm{O}-\mathrm{Sil}\end{array}$ & $4.19-5.88$ & $(5.04 \pm 0.01)$ \\
\hline
\end{tabular}

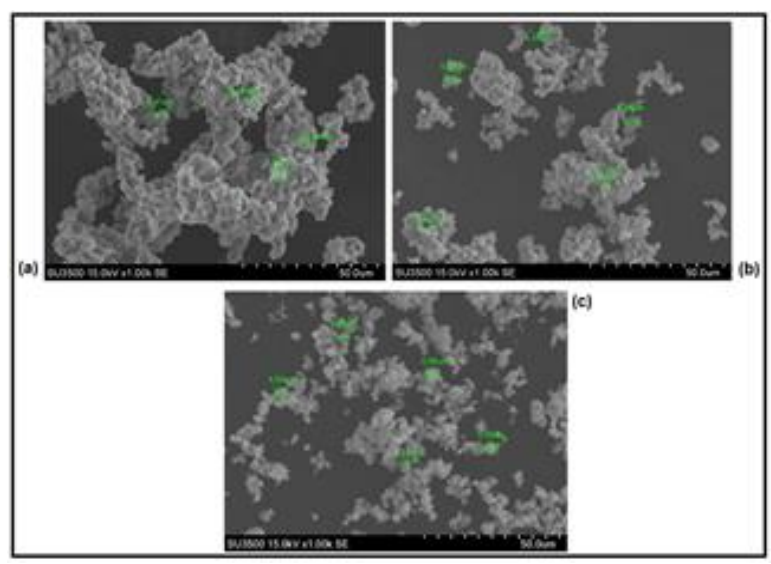

Figure 1. SEM image of 2x jet milled samples with $3 \%(a), 5 \%$ (b), and $10 \%$ (c) Cab-O-Sil. 1000x magnification

Figure 2 shows the SEM images of samples that were jet-milled 3x. Based on Figure 2 , the particle sizes of $3 x$ jet-milled samples were also generally in the range of 2-5 $\mu \mathrm{m}$ with smaller sizes. The particle sizes of the $3 x$ jet-milled samples were 3.60-6.58 $\mu \mathrm{m}$ (mean $=4.97 \pm 0.01$ $\mu \mathrm{m})$ for sample without Cab-O-Sil, 4.12-6.20 $\mu \mathrm{m}$ (mean $=5.15 \pm 0.01 \mu \mathrm{m})$ for sample with $3 \%$ CabO-Sil, 3.77-4.60 $\mu \mathrm{m}$ (mean $=4.51 \pm 0.01) \mu \mathrm{m}$ for sample with $5 \%$ Cab-O-Sil, and 3.07-3.84 $\mu \mathrm{m}$ $($ mean $=3.31+0.01 \mu \mathrm{m})$ for sample with $10 \%$ Cab-O-Sil. In addition, based on Figure 2, much less clumping appeared in the morphology of samples with either $5 \%$ or $10 \%$ Cab-O-Sil, so that $5-10 \%$ Cab-O-Sil was an optimal composition for the $3 x$ jet-milled samples. This was probably due to the high tendency of samples with less 
composition of Cab-O-Sil to absorb moisture and agglomerate.

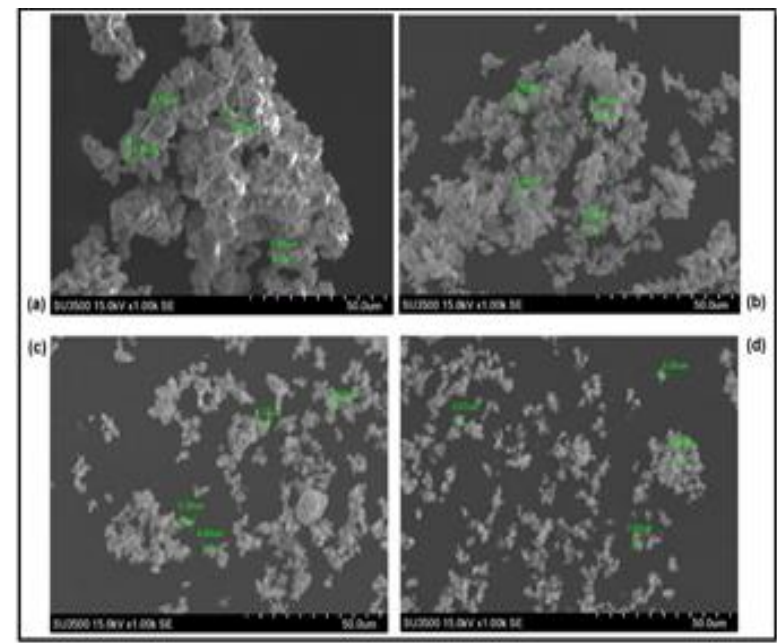

Figure 2. SEM image of $3 x$ jet milled samples with $0 \%(a), 3 \%(b), 5 \%(c)$, and 10\% (d) Cab-OSil. $1000 x$ magnification

In general, those sizes were in the range of 2-5 $\mu \mathrm{m}$ with the optimal composition of $5-10 \%$ Cab-O-Sil based on the clumping appearance. The sizes of the $2 x$ jet-milled samples were slightly bigger than the particle sizes of the $3 x$ jetmilled samples.

Table 2 depicts the result of particle analysis and size distribution measurements by Particle Size Analyzer Nano DS Cilas (Nano Plus Particulate System) in Research Center for Material BPPT. Based on Table 2, powder samples with $2 x$ jet-milled and $10 \%$ Cab-O-Sil ware the optimal combination. Sample with $2 x$ jetmilled and 10\% Cab-O-Sil have mean diameter $2.436 \mu \mathrm{m}$, cumulant diameter $1.928 \mu \mathrm{m}, \mathrm{D}(10 \%)$ diameter $1.326 \mu \mathrm{m}, \mathrm{D}(50 \%)$ diameter $2.230 \mu \mathrm{m}$, and $\mathrm{D}(90 \%) 3.737 \mu \mathrm{m}$. Meanwhile, powder samples with $3 x$ jet-milled and $10 \%$ Cab-O-Sil has mean diameter particles $0.366 \mu \mathrm{m}$ and cumulant diameter particles $0.308 \mu \mathrm{m}$.

Table 2. PSA measurement of jet-milled powder samples in Research Center for Materials BPPT.

\begin{tabular}{|l|l|l|l|l|l|l|}
\hline $\begin{array}{c}\text { Number } \\
\text { of } \\
\text { milling }\end{array}$ & $\begin{array}{c}\text { Cab-O-Sil } \\
\%\end{array}$ & $\begin{array}{c}\text { Mean } \\
\text { Diameter } \\
(\mu \mathrm{m})\end{array}$ & $\begin{array}{c}\text { Cumulant } \\
\text { Diameter } \\
(\mu \mathrm{m})\end{array}$ & $\begin{array}{c}\mathrm{D}(10 \%) \\
(\mu \mathrm{m})\end{array}$ & $\begin{array}{c}\mathrm{D}(50 \%) \\
(\mu \mathrm{m})\end{array}$ & $\begin{array}{c}\mathrm{D}(90 \%) \\
(\mu \mathrm{m})\end{array}$ \\
\hline $2 \mathrm{x}$ & $3 \%$ & 4.493 & 3.578 & 2.348 & 4.137 & 6.933 \\
\hline $2 \mathrm{x}$ & $5 \%$ & 8.166 & 6.184 & 4.123 & 7.421 & 12.78 \\
\hline $2 \mathrm{x}$ & $10 \%$ & 2.436 & 1.928 & 1.326 & 2.230 & 3.737 \\
\hline $3 \mathrm{x}$ & $3 \%$ & 0.102 & 0.079 & 0.051 & 0.093 & 0.163 \\
\hline $3 \mathrm{x}$ & $5 \%$ & 0.006 & 0.005 & 0.003 & 0.005 & 0.008 \\
\hline $3 \mathrm{x}$ & $10 \%$ & 0.366 & 0.308 & 0.220 & 0.343 & 0.527 \\
\hline
\end{tabular}

Based on the experiments' results, it was concluded that the optimal method among parameters explored to get salt particles of 2-5 $\mu \mathrm{m}$ was as below:

As much as $1 \mathrm{~kg}$ crude seawater salt was crushed manually by using mortar. The manually crushed salt was then heated at $125^{\circ} \mathrm{C}$ for 1 hour.
After that, the heated salt was milled by using Cross-Beather Mill two times, both were at a mill speed of 2000 RPM. The 1st milling used an output screen of $1 \mathrm{~mm}$, while the 2 nd one used an output screen of $0.5 \mathrm{~mm}$. The twice milled sample was then sieved by using a sieve shaker for 10 minutes. The sieves were those of 180 micrometer, 150 micrometer, and 75 micrometers. Below the stack of the sieves was the pan that collected the fraction of sample with the lowest sizes ( $<75$ micrometers). This sample was mixed manually with Cab-O-Sil as much as $10 \%$. The mixture was then heated at $125^{\circ} \mathrm{C}$ for 1 hour. Finally, the re-heated mixture sample was milled by using a jet mill two times.

\section{CONCLUSION}

In this research, a $\mathrm{NaCl}$-based 2-5 $\mu \mathrm{m}$ seeding material prototype has been prepared. In order to produce materials with such size ranges, a combination of repeated milling, sieving, and jet milling process must be done. Further study is deemed necessary to bring about the $\mathrm{NaCl}+10 \%$ cab-o-sil mixture as a potential 2-5 $\mu \mathrm{m}$ seeding material in the fabrication scale.

\section{REFERENCES}

Braham, R.R. (1986). Precipitation Enhancement-A Scientific Challenge. Meteorological Monograph. American Meteorological Society. doi: 10.1007/978-1935704-17-1_1

Bruintjes, R.T. (1999). A review of cloud seeding experiments to enhance precipitation and some new prospects. Bull. Amer. Meteor. Soc., 80, 805-820. doi: 10.1175/15200477(1999)080<0805:AROCSE>2.0.CO;2

Clark, A.R., Hsu, C.C., Walsh, A.J., (1996). Preparation of Sodium Chloride Aerosol Formulations. Genentech, Inc., South San Francisco, CA, 15pp, US5747002.

Cooper, W.A., Bruintjes, R.T., and Mather, G.K. (1997). Calculations pertaining to hygroscopic seeding with flares. J. Appl. Meteor., 36, 1449-1469. doi: $10.1175 / 1520-$ 0450(1997)036<1449:CPTHSW>2.0.CO;2

Czys, R.R., and Bruintjes, R.T. (1994). A review of hygroscopic seeding experiments to enhance rainfall. J. Wea. Mod., 26, 41-52.

Drofa, A.S., Ivanov, V.N., Rosenfeld D., and Shilin, A.G. (2010). Studying an effect of salt powder seeding used for precipitation enhancement from convective clouds. Atmos. Chem. Phys., 10, 8011- 8023.

Gary Liu, P.E. (2017). Hammer Milling and Jet Milling Fundamentals. American Institute of Chemical https://www.aiche.org. 48-54.
Engineers. 
Gommeren, H.J.C, Heitzmann, D.A., Kramer, H.J.M, Heiskanen, K., and Scarlett, B. (1996). Dynamic modeling of a closed loop jet mill. Int. J. Miner. Process., 44-45, 497506.

Harmon, C.W., Grimm, R.L., Mclntire, T.M., Peterson, M.D., Njegic, B., Angel, V.M., Alshawa, A., Underwood, J.S., Tobias, D.J., Gerber, R.B., Gordon, M.S., Hemminger, J.C., dan Nizkorodov, S.A. (2010). Hygroscopic growth and deliquescence of $\mathrm{NaCl}$ nanoparticles mixed with surfactant SDS. J. Phys. Chem. B., 114(7), 24352449. doi: 10.1021/jp909661q

McFiggans, G., Artaxo, P., Baltensperger, U., Coe, H., Facchini, M.C., Feingold, G., Fuzzi, S., Gysel, M., Laaksonen, A., Lohmann, U., Mentel, T.F., Murphy, D.M., O'Dowd, C.D., Snider, J.R., Wingartner. (2006). The effect of physical and chemical aerosol properties on warm cloud droplet activation. Atmos. Chem. Phys., 6(9), 25932649. doi: 10.5194/acp-6-2593-2006
Rosenfeld, D., Axisa, D., Woodley, W.L., and Lahav, R. (2010). A Quest for Effective Hygroscopic Cloud Seeding, J. Appl. Meteorol. Clim., 49, 1548-1562. doi: 10.1175/2010JAMC2307.1

Segal, Y., Khain, A., Pinsky, M., and Rosenfeld, D. (2004). Effects of hygroscopic seeding on raindrop formation as seen from simulations using a 2000-bin spectral cloud parcel model. Atmos. Res., 71, 3-34. doi: 10.1016/j.atmosres.2004.03.003

Silverman, B.A., Sukarnjanaset, W., (2000). Results of the Thailand warm-cloud hygroscopic particle seeding experiment. J. Appl. Meteorol., 39, 1160- 1175. doi: 10.1175/1520-

0450(2000)039<1160:ROTTWC>2.0.CO;2

Sullivan, R.C., Moore, M.J.K., Petters, M.D., Kreidenweis, S.M., Roberts, G.C., Prather, K.A. (2009). Effect of chemical mixing state on the hygroscopicity and cloud nucleation properties of calcium mineral dust particles. Atmos. Chem. Phys. 9(10), 3303-3316. doi: 10.5194/acp-9-3303-2009 